\title{
Composites Prepared via Friction Stir Processing Technique: A Review
}

\author{
Manish Maurya $^{1^{*}}$, Sudhir Kumar ${ }^{2}$, Nagendra Kumar Maurya ${ }^{3}$ \\ ${ }^{1}$ Department of Mechanical Engineering, Accurate Institute of Management and Technology, Greater Noida 201308, India \\ ${ }^{2}$ Department of Mechanical Engineering, Greater Noida Institute of Technology, Greater Noida 201308, India \\ ${ }^{3}$ Department of Mechanical Engineering, G. L. Bajaj Institute of Technology and Management, Greater Noida 201308, India
}

Corresponding Author Email: manish.maurya@accurate.in

https://doi.org/10.18280/rcma.303-404

Received: 24 November 2019

Accepted: 17 January 2020

\section{Keywords:}

metal matrix composites (MMCs), microstructure, micro-hardness, wear rate and tribological properties

\begin{abstract}
This review article investigates the mechanical and tribological properties of metal matrix composites (MMCs) prepared through friction stir processing technique. MMCs are developed materials with enhanced mechanical properties, exhibits their application in automotive and aerospace industries. The limitations of liquid metallurgical route can be reduced by using Friction Stir Processing (FSP) technique. FSP, a developed methodology technologically advanced by friction stir welding process is reviewed to fabricate the MMCs. In FSP, a hole or groove is made in the alloy. Reinforcement filled in the groove or hole are distributed in the matrix material by the FSP tool. Heat produced between the tool and the surface tends to the grain refinement. Owing to grain refinement, mechanical and wear properties of the composites are enhanced. In this review article, mechanical and wear behavior of the composite developed through FSP method are reviewed, which will help the researchers and industrial societies to fabricate the composite of required enhanced properties.
\end{abstract}

\section{INTRODUCTION}

Aluminum and its alloys have achieved extensive acceptance in different technological uses due to their specific high strength to weight ratio. The composites were formed when alloys were reinforced with ceramics like $\mathrm{SiC}, \mathrm{TiC}, \mathrm{ZrO}_{2}$ and $\mathrm{B}_{4} \mathrm{C}[1]$ etc. Figure 1 shows different types of composites formed by reinforcing different materials.

Composites have got improved mechanical and wear characteristics as compared to base alloy. Mechanical, wear and tribological properties of the fabricated composites were investigated by various researchers. The limitations of MMCs observed was the loss of ductility, which limits its application. Various processing techniques like mechanical stir casting, powder metallurgy, electromagnetic stir casting etc. are present in the current scenario [2-4]. Friction stir welding (FSW) was developed by The Welding Institute (TWI) at UK in 1991 as a solid-state joining process. Friction stir processing is newly emerged technique developed through FSW to develop surface composites. FSP technique is unable to fabricate bulk composites [5].

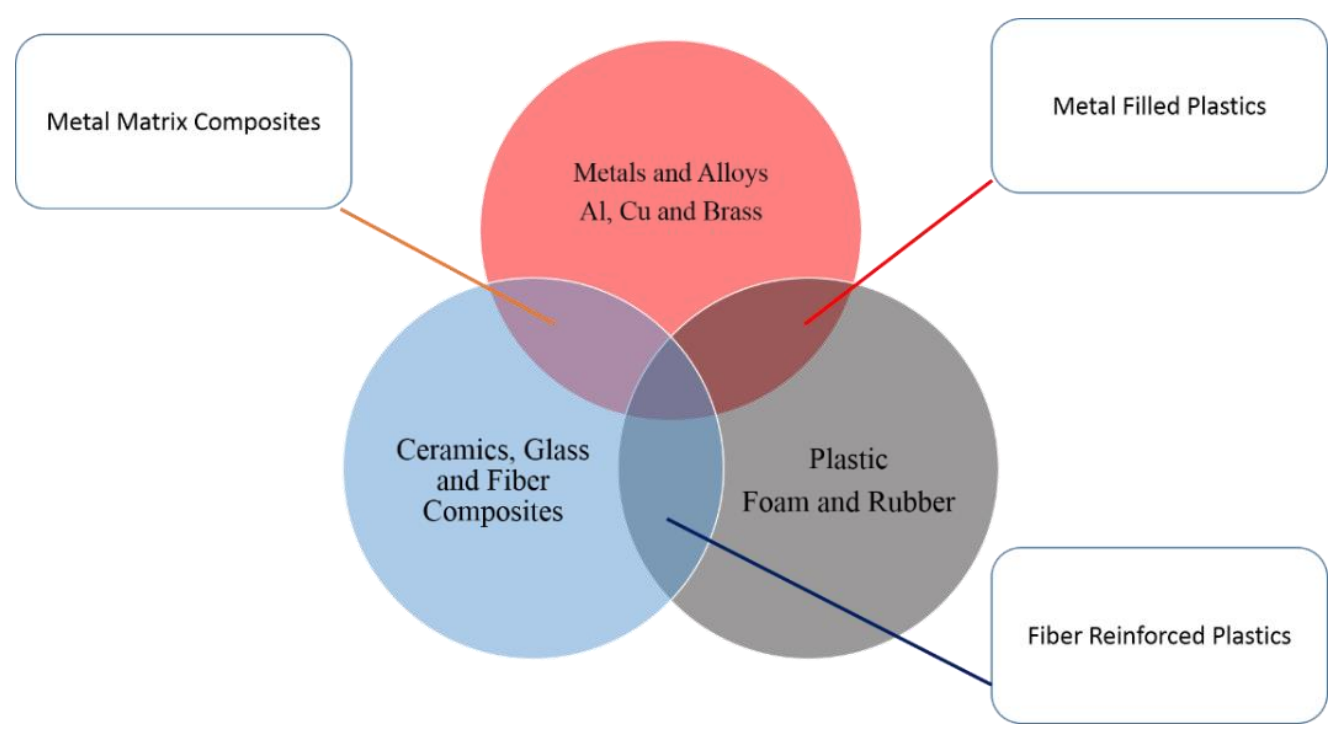

Figure 1. Composite formation with different reinforced materials 


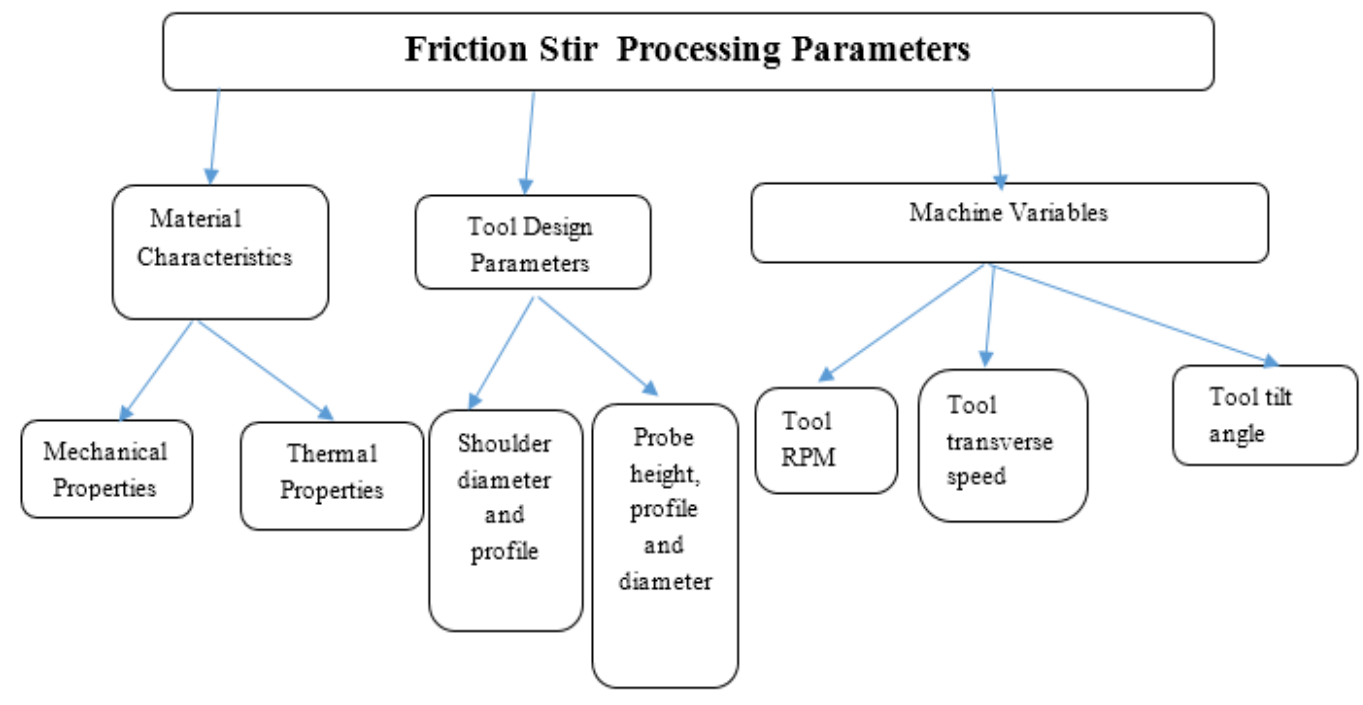

Figure 2. Classification of FSP process parameters

In FSP, non-consumable rotating tool is stirred above the specimen. The applied axial force on the tool had produced the interaction between the developed sample and tool, had resulted the heat formation. The reinforced particle works as a grain nucleating site inside the solidifying specimen which obstruct the grain growth of the aluminum alloy. Thus, a consistent decrease in grain size with increased reinforcement of uniformly distributed reinforced particles was observed [5]. Secondly, FSP technique leads to intense plastic deformation that neutralizes the pinning effect. The occurrence of pulled out and fractured particles accept proof to better have interfacial bonding. The heat produced from FSP tool inclines to plastic flow of material. Plastic flow of material leads to grain refinement. Generally, reinforcements were filled by two techniques in the base alloy. One was by drilling a hole and the other by cutting a groove in the base alloy. The classification of FSP process parameters is shown in Figure 2.

\section{APPROACH FOR INVESTIGATING THE LITERATURE}

This review article has been prepared on the analysis of published research work (from 2014 to 2018) on the fabrication and evaluation of mechanical properties of FSPed composites. This literature review is accompanied as a content investigation in which the mechanical propertied of FSPed composites are evaluated. The main source of collecting literature survey was (1) review articles (2) conferences (3) theory and notes of FSP and (4) research articles. In this review article, the assessment of FSP methodology to fabricate the composite is discussed. The literature section is categorized into two sections. The first section includes microstructural and mechanical properties while the other section deals with tribological behavior of the composites. The results of hardness, tensile and wear test obtained by various researchers is evaluated in the tabular form. The detailed summary of the research work is reported in the next sub section.

\subsection{Microstructural and mechanical properties of FSPed composite}

Arab et al. [6] investigated the yield and tensile strength of
Al 1100/E glass, S glass and carbon reinforced composite fabricated through FSP method. Al 1100/S glass composite had maximum yield strength (75 $\mathrm{MPa})$ and tensile strength (130 $\mathrm{MPa})$ in comparison to $\mathrm{E}$ glass and carbon reinforced composites.

Sharma et al. [7] observed the microstructural and mechanical properties of AA 2014/SiC composite by FSP. Experimental results revealed that change in grain size of microstructure from thermo mechanical affected zone and stirred zone was observed. The maximum hardness of $150 \mathrm{HV}$ was found for AA 2014/SiC composite. FSPed AA 2024/SiC composite was fabricated by Hosseinzadeh et al. [8] to investigate the mechanical properties. The hardness and yield strength were enhanced by $50 \%$ and notable $240 \%$. Yang et al. [9] investigated the microstructural and mechanical properties of AA 2024/ $\mathrm{Al}_{2} \mathrm{O}_{3}$ composite prepared through FSP. The micro hardness was improved to $155 \mathrm{Hv}$ and tensile strength of cold sprayed composite was improved by FSP method.

Sahraeinejad et al. [10] prepared $\mathrm{Al} 5059 / \mathrm{Al}_{2} \mathrm{O}_{3}, \mathrm{SiC}$ and $\mathrm{B} 4 \mathrm{C}$ reinforced composite by FSP technique to observe the microstructural and mechanical properties. $\mathrm{Al}_{2} \mathrm{O}_{3}$ reinforced composite had better grain refinement in compare to $\mathrm{SiC}$ and B4C particles. $\mathrm{Al} 5359 / \mathrm{B}_{4} \mathrm{C}$ composite had higher tensile and yield strength with reduced ductility as compared to $\mathrm{Al}_{2} \mathrm{O}_{3}$ and $\mathrm{SiC}$ reinforced composite. The ball milling and particle size effect on FSPed A15083/Ni surface composite was evaluated by Kumar et al. [11]. The particle's size of $10 \mu \mathrm{m}$ was refined by ball milling, had got uniform distribution of the reinforcement. The ductility and hardness of Al5083/Ni composite was reduced as compared to received $\mathrm{Ni}$ particles. Bauri et al. [12] investigated the optimum tool rotation speed and transverse speed to prepare defect free stir zone of $\mathrm{Al}$ 5083/Ni surface composite prepared through FSP. The minimum 1,200 rpm of tool rotational speed and $0.4 \mathrm{~mm} / \mathrm{sec}$ of transverse speed was required to incorporate $\mathrm{Ni}$ particles. During recrystallization of the matrix, the grain size was abridged from 25 to $3 \mu \mathrm{m}$.

Huang and Shen [13] fabricated Al 5083/Ti composite via FSP to investigate the mechanical properties of composite under air and water processing environments. Finer recrystallized grain in the composite was accomplished due to influence of cold water on it, had increased the tensile and yield strength. Papantoniou et al. [14] studied the microstructural properties of AA 5083/MWCNT composite 
prepared through FSP. Optical microscopy and scanning electron microscope were used to observe the microstructural behavior of the prepared composite. It was observed that the distribution of micro hardness was perpendicular to the transverse speed of FSP tool.

Kishan and Devraju [15] prepared Al 6061/nano $\mathrm{TiB}_{2}$ composite by FSP technique to observe the microstructural properties. The micro hardness of the composited was improved to $132 \mathrm{Hv}$ as compared to base alloy having $104 \mathrm{Hv}$. The decrease in tensile strength was observed due to accumulation of $\mathrm{TiB}_{2}$ particles [15]. Dinaharan and Akinlabi [16] prepared FSPed composite made of AA 6061, AZ31 and $\mathrm{Cu}$ alloy incorporated with fly ash. The plate of $10 \times 50 \mathrm{~mm}$ was used to make a groove. The groove was filled with fly ash particles of size $5 \mu \mathrm{m}$. The optical micrograph results revealed uniform dispersal of reinforced content. The nature of FSP that is plastic deformation in solid state had reduced the free movement of reinforced FA particles. The operative stirring action of FSP tool had avoid the agglomeration of FA particles. The micro hardness of AZ31/FA composite was obtained to be 110.29 VHN.

Dhayalan et al. [17] developed AA 6063/SiC-Gr composite by FSP method to observe the microstructural properties. Optical microscopy results revealed that stirred zone had maximum refined grain structure as compare to heat affected or transition zone. The maximum micro hardness of AA 6063/SiC surface composite was improved to $62 \mathrm{Hv}$. Rathee et al. [18] fabricated AA $6063 / \mathrm{SiC}$ composite via FSP to investigate the influence of groove width to pin diameter on the mechanical characteristics. The ratio (w/d) of 0.5 was obtained to yield defect free composite. The micro hardness and tensile strength were improved to $80 \mathrm{Hv}$ and $175 \mathrm{MPa}$. The influence of multi pass FSP on AA 6063-T6Al /SiC composite was evaluated by Gangil et al. [19]. With the increase in number of passes, finer recrystallized grain structure was observed. Abraham et al. [20] prepared AA 6063/SiO2 composite via FSP methodology to investigate the micro hardness and wear properties. The micro hardness of stir zone was improved to $135 \mathrm{Hv}$ at 18 vol. $\% \mathrm{SiO}_{2}$. The refinement of grain size has increased the micro hardness of surface composite. The wear rate of the composite was reduced to $258 \times 10^{-5} \mathrm{~mm}^{3} / \mathrm{m}$ at 18 vol. $\%$.

FSPed Al 6082/Mo composite was developed by Selvakumar et al. [21]. The UTS was improved to $305 \mathrm{MPa}$ at 18 vol. $\%$ while ductility was reduced by $24 \%$ for $\mathrm{Al} 6082 / \mathrm{Mo}$ composite. Selvakumar et al. [22] prepared AA 6082/ stainless steel composite through FSP to enhance the ductility. SEM results revealed that no any particle free region was observed in the stirred zone. The UTS was improved to $293 \mathrm{MPa}$ at 18 vol. $\%$ while ductility was measured to be $17 \%$ at 18 vol. $\%$.

Du et al. [23] fabricated Al/A12O3/CNTs composite by FSP method to investigate the microstructural properties. Grain refinement had resulted in the improvement of the mechanical properties of $\mathrm{Al} / \mathrm{Al}_{2} \mathrm{O}_{3} / \mathrm{CNT}$ s composite. 108.4 $\mathrm{HV}$ and 263 $\mathrm{MPa}$ was the micro hardness and tensile strength for the prepared composite. Microstructural and mechanical properties of FSPed $\mathrm{Cu} /$ Rice husked ash composite was investigated by Dinaharan et al. [24]. Strong interfacial bonding was formed between $\mathrm{Cu}$ matrix and the rice husked ash particles. The micro hardness was found to be $105 \mathrm{VHN}$. The wear rate was reduced to $5.3 \times 10^{-3} \mathrm{~mm}^{3} / \mathrm{m}$ by incorporating $18 \mathrm{vol} \%$ of the particles. Kurtyka et al. [25] investigated the mechanical characteristics of A 339/SiC composite prepared through FSP method. The compressive strength was maximum in advancing side. $30 \%$ increase in hardness and $40 \%$ increase in compressive strength was obtained.

\subsection{Tribological behavior of FSPed composite}

Janbozorgi et al. [26] investigated the mechanical and wear characteristics of $\mathrm{A} 413 / \mathrm{SiC}$ and $\mathrm{A} 413 / \mathrm{SiC} / \mathrm{MoS}_{2}$ composite prepared through FSP. MoS2 lubricant contents had reduced the micro hardness of the $\mathrm{A} 413 / \mathrm{SiC} / \mathrm{MoS}_{2}$ composite. This was due to reduced hardness of $\mathrm{MoS}_{2}$ lubricant. $105 \mathrm{Hv}$ was the maximum hardness for non-lubricated A413/SiC composite. The wear loss was reduced with lubricating $\mathrm{SiC}$ particles by $\mathrm{MoS}_{2}$.

Golmohammadi et al. [27] prepared A 413/Ni surface composite by FSP method to observe the mechanical and wear characteristics. Three pass composites had got higher micro hardness of $80 \mathrm{Hv}$ as compared to casted or single pass composite. Wear resistance was improved for three pass composites in comparison to casted or single pass composite. Esfahani et al. [28] investigated the wear properties of $\mathrm{Al}$ 1050/Fe surface composite fabricated via FSP. Two pass FSP had improved the grain size of the stirred zone composite. 70 VHN was the micro hardness found in the nugget zone. Fe particles in the surface of Al 1050 alloy had better wear resistance in comparison to Al 1050 alloy.

Abreu et al. [29] developed AA 2024/SiC composite by FSP method to investigate the tribological properties. The presence of $\mathrm{SiC}$ content had amplified the micro hardness of AA 2024/SiC composite to $145 \mathrm{Hv}$. The wear rate was reduced in the processed zone to $2.64 \times 10^{-4} \mathrm{~mm}^{3} / \mathrm{Nm}$. Yuvaraj et al. [30] examined the tribological characteristics of $\mathrm{Al} 5083 / \mathrm{B}_{4} \mathrm{C}$ micro and nano surface composite prepared through FSP technique. The micro hardness of nano composite was enhanced to $122 \mathrm{Hv}$, having three number of passes. Wear resistance of nano composite was increased due to hard $\mathrm{B}_{4} \mathrm{C}$ particles embedded in the surface of Al 5083 alloy. Kumar et al. [31] evaluated the wear characteristics of $\mathrm{Al} 5083 / \mathrm{W}$ composite developed through FSP method. The groove of $60 \times 2 \times 1.5 \mathrm{~mm}$ was made on Al 5083 plate, having thickness $10 \mathrm{~mm}$. Tungsten particles of $10 \mu \mathrm{m}$ were kept in the groove. FSP tool was rotated at 1,200 rpm having transverse speed of $2 \mathrm{~mm}$. Uniform distribution was observed in the microstructure. EDM was used to cut the wear test samples of diameter $8 \mathrm{~mm}$ and height of $10 \mathrm{~mm}$. Wear rate was less in comparison to base and FSPed alloy under different loading conditions. Mirjavadi et al. [32] studied the mechanical and wear behavior of AA 5083/ $\mathrm{ZrO}_{2}$ composite prepared through FSP. Composite having 8 passes had got the maximum grain refined structure, with micro hardness of $140 \mathrm{Hv}$. Wear rate was also reduced for composite prepared through 8 number of passes. Jain et al. [33] investigated the mechanical and wear properties of AA5083- $\mathrm{B}_{4} \mathrm{C} / \mathrm{SiC} / \mathrm{TiC}$ composite prepared by FSP. Experimental results concluded that the tensile strength and micro hardness was improved to be $349 \mathrm{MPa}$ and 132.56 $\pm 2.52 \mathrm{Hv}$ for AA $5083 / \mathrm{B}_{4} \mathrm{C}$ composite as compared to AA $5083 / \mathrm{SiC} / \mathrm{TiC}$ composite. $18 \times 10^{-5} \mathrm{~mm}^{3} / \mathrm{Nm}$ was the minimum wear rate for AA 5083/B4C composite.

The effect of process parameters on the stirred zone for FSPed Al 5456/ $\mathrm{BNi}_{2}$ composite was investigated by Esmaily et al. [34].10 $\mathrm{mm} / \mathrm{min}$ was the best tool transverse speed to avoid agglomeration of $\mathrm{BNi}_{2}$ particles. The tool having speed of $30 \mathrm{~mm} / \mathrm{min}$ had uniform distribution of reinforced particles, along with fine grain structure. V shape and step grove had got 
more uniform distribution in comparison to square groove. The maximum hardness was achieved to be $120 \mathrm{HB}$ in the stirred zone for $\mathrm{Al} 5456 / \mathrm{BNi}_{2}$ composite.

Rao and Rao [35] evaluated the wear behavior of AA $6061 / \mathrm{TiB}_{2}$ composite prepared by FSP. The micro hardness was enhanced to $135 \mathrm{HV}$. $\mathrm{TiB}_{2}$ reinforced composite had minimized the wear resistance of the AA $6061 / \mathrm{TiB}_{2}$ composite. Kishan et al. [36] investigated the tribological behavior of $\mathrm{Al}$ 6061/nano $\mathrm{TiB}_{2}$ composite prepared via FSP method. The depth of prepared nano surface layer was $3863.83 \mu \mathrm{m}$. The micro hardness of the prepared composite was improved to 132 Hv. 4 vol. \% of nano TiB2 composite exhibit the maximum wear resistance as compared to 2 or 6 vol. $\%$ of $\mathrm{TiB}_{2}$ nano particles [36].

The influence of transverse speed AA 6082/TiC composite fabricated through FSP technique was evaluated by Thangarasu et al. [37]. The area of stirred zone was reduced by the increase of transverse speed. Non uniform dispersal of TiC content was observed at higher transverse speed. The maximum micro hardness was found to be $135 \mathrm{HV}$ at 80 $\mathrm{mm} / \mathrm{min}$ with minimum wear rate of $412 \times 10^{-5} \mathrm{~mm}^{3} / \mathrm{m}$ at 80 $\mathrm{mm} / \mathrm{min}$. Thangarasu et al. [38] fabricated AA 6082/TiC composite through FSP technique to investigate microstructural and mechanical properties. The maximum micro hardness and UTS was found to be $149 \mathrm{HV}$ and 222 MPa by incorporating 24 vol. $\%$ of TiC particles. The wear rate was reduced with the increased volume $\%$ of TiC particles [38]. The empirical relationship was by Thangarasu et al. [39] to evaluate the mechanical and wear characteristics of AA 6082/ $\mathrm{SiC}, \mathrm{Al}_{2} \mathrm{O}_{3}, \mathrm{TiC}, \mathrm{B}_{4} \mathrm{C}$ and $\mathrm{WC}$ composite prepared via FSP. TiC reinforced composite had maximum micro hardness of $115 \mathrm{Hv}$ and, minimum wear rate as compared to $\mathrm{SiC}, \mathrm{Al}_{2} \mathrm{O}_{3}$, $\mathrm{B}_{4} \mathrm{C}$ and $\mathrm{WC}$ particles. Thangarasu et al. [40] investigated the wear properties of AA 6082/TiC composite by FSP method. Increased wt $\%$ of $\mathrm{TiC}$ content had improved the wear resistance, found to be $0.00303 \mathrm{mg} / \mathrm{m}$ at $22 \mathrm{vol} . \%$.

Ambigai and Prabhu [41] performed the experiment to observe the tribological behavior of $\mathrm{Al} / \mathrm{B}_{4} \mathrm{C}$ micro/nano composite fabricated through FSP. The wear characteristics were observed on pin-on disc machine. The mass loss, volume loss, wear rate and coefficient of friction were investigated for different loading and sliding distance conditions. It was observed that $\mathrm{Al} / \mathrm{B}_{4} \mathrm{C}$ nano composite had less wear loss as compared to $\mathrm{Al} / \mathrm{B}_{4} \mathrm{C}$ micro composite. ANOVA had depicted that normal load had maximum influence on the wear property. The increase in normal load had reduced the coefficient of friction due to development of tribo layer on the contact of surface [41]. Bhat et al. [42] prepared $\mathrm{Al} / \mathrm{Fe}$ composite through FSP to evaluate the microstructure and creep behavior. Experimental results revealed that FSPed zone had uniform reinforcement of Fe particles. High degree metastability had leaded the poor creep resistance on the stirred zone.

Rajan et al. [43] developed AA 7075/ $\mathrm{TiB}_{2}$ composite via FSP technique to investigate the mechanical characteristics. Excellent interfacial bonding between TiB2 and alloy had strengthened the mechanical properties of AA $7075 / \mathrm{TiB}_{2}$ composite. The maximum micro hardness and UTS was obtained to be $160 \mathrm{VHN}$ and $340 \mathrm{MPa}$. Wear rate was reduced for FSPed AA 7075/ $\mathrm{TiB}_{2}$ composite. Wear properties of FSPed $\mathrm{Al} 7075 / \mathrm{B}_{4} \mathrm{C}$ composite was evaluated by Rana et al. [44]. The groove of $100 \times 1.2 \times 2.5 \mathrm{~mm}$ was made in $\mathrm{Al} 7075$ plate through shaper machine. $\mathrm{B}_{4} \mathrm{C}$ particles of $12-15 \mu \mathrm{m}$ were incorporated in the groove. FSP tool of WC-Co (12\%) was rotated at $545 \mathrm{rpm}$ having tool tilt angle of 3o. Lowest transverse speed has uniform dispersal of B4C particles in the nugget zone. Increased transverse speed had reduced the micro hardness of the composite. This was due to reduced stir time and insufficient time for grain refinement of the particles. Kumar et al. [45] observed the mechanical properties of $\mathrm{Al}$ 7075/SiC micro and nano composite fabricated through FSP. Tensile strength was improved up to $190 \%$ in nano composites. Nano composites possess better wear resistance in comparison to micro reinforced composites. Eskandari and Taheri [46] fabricated $\mathrm{Al} 8026 / \mathrm{TiB}_{2} / \mathrm{Al}_{2} \mathrm{O}_{3}$ hybrid nano composite via FSP to evaluate the micro hardness. Microhardness was enhanced to $175 \mathrm{Hv}$, as compared to base alloy having $85 \mathrm{Hv}$.

Zangabad et al. [47] prepared $\mathrm{Al} / \mathrm{Al} 3 \mathrm{Ti} / \mathrm{MgO}$ hybrid nano composite by FSP route to observe the fatigue fracture. Optical microscopy results revealed homogeneous distribution of reinforced particles. Increased $\mathrm{TiO}_{2}$ content had increased the tensile and yield strength. Hard inclusions had strengthened the fatigue strength of the composite. Azizieh et al. [48] prepared $\mathrm{Al} / \mathrm{Al}_{2} \mathrm{Cu}$ nano composite through FSP to investigate the micro structural and wear properties. Experimental results concluded that the micro hardness was increased with the increase in number of passes up to an extent. The micro hardness was improved to $53 \mathrm{Hv}$ at tool rotation speed of 1120 $\mathrm{rpm}$, transverse speed of $56 \mathrm{~mm} / \mathrm{min}$ and 4 passes of FSP.

\section{ADVANTAGE OF FSP METHOD}

FSP had got advantages when two materials were mixed by solid state processing route. Through FSP, the microstructural refinement, densification and homogeneity was obtained [49]. FSP helps to modify the materials without porosity and casting defects, generally generated in liquid metallurgical route. For example, FSP can simply modify the form of a piece sheets metal with the enhancement of mechanical and wear properties, where before it had to be melted down before and put into a mold to cool and form the sheet. The microstructural, mechanical and tribological characteristics of the stirred zone can be precisely monitored by selecting the FSP parameters and tool design [50]. The same sheet of metal can be changed to fit different conditions with the suitable alteration of the tool design. FSP has proved to prepare metallic alloys bendable as for example an alloy altered with FSP would be capable to bend to 35 degrees as before it could only bend to eight degree.

\section{APPLICATION OF FSP TECHNIQUE}

The FSP was used to improve the mechanical properties by using other metals or alloys for support and enhancement of the first. This was favorable route for the automotive, armors, defence and aerospace industries where new material was to be established with improved wear resistance, creep, and fatigue [51]. Examples of composites successfully developed using the FSP technique includes AA 6082/ stainless steel, AA 6082/TiC, AA 6063/ $/ \mathrm{SiO}_{2}, \mathrm{Al} 5083 / \mathrm{Ni}, \mathrm{Al} 5083 / \mathrm{Ti}$ and AA $7075 / \mathrm{TiB}_{2}$ etc. 


\section{SUMMARY AND FUTURE SCOPE}

From the review of different range of previously reported work, it is clear that lots of work have been reported on FSP over the last several years. The main reason for this interest was significant improvement on mechanical and tribological properties with addition of different reinforcement through solid metallurgical route. Table 1 shows the summary of previously reported work on composite fabrication by using the FSP technique. Figure 3 shows the summary of percentage contribution of research work reported related to the mechanical and wear properties. It can be clearly seen that the major focus of researchers were to evaluate the hardness, tensile strength and wear rate of the composite fabricated via
FSP. However it was noticed that very less work have been reported related to other important mechanical properties like fatigue strength, creep and compressive strength etc. Eighty percent of the mechanical components were failed due to the fatigue failure. So more work related to fatigue behavior are required to understand the effect of reinforcement on fatigue strength of aluminium composite. Figure 4 shows the summary of percentage contribution of research work on different reinforcement particles for the fabrication of composite. It can be observed that most of the research works were carried out by using $\mathrm{SiC}, \mathrm{B}_{4} \mathrm{C}, \mathrm{TiB}_{2}$ and $\mathrm{TiC}$. From the reported work, it was observed that the mechanical and tribological properties of aluminium was maximum by $\mathrm{B}_{4} \mathrm{C}$ reinforcement.

Table 1. Summary on Composite Fabrication using FSP

\begin{tabular}{|c|c|c|c|c|c|}
\hline S.NO. & Authors & $\begin{array}{c}\text { Al Matrix / } \\
\text { Reinforcement }\end{array}$ & Properties Evaluated & $\begin{array}{c}\text { Micro } \\
\text { Hardness }\end{array}$ & Prominent Results \\
\hline 1 & Arab et al. [6] & $\begin{array}{l}\text { Al 1100/E glass, } \\
\text { S glass and } \\
\text { carbon }\end{array}$ & Mechanical Properties & & $\begin{array}{l}\text { Al 1100/S glass composite had yield } \\
\text { strength of } 75 \mathrm{MPa} \text {, and tensile strength } \\
\text { of } 130 \mathrm{MPa} \text {. }\end{array}$ \\
\hline 2 & Sharma et al. [7] & AA $2014 / \mathrm{SiC}$ & $\begin{array}{l}\text { Mechanical } \\
\text { Characteristics }\end{array}$ & $150 \mathrm{HV}$ & $\begin{array}{l}\text { Change in grain size of microstructure } \\
\text { from thermo mechanical affected zone } \\
\text { and stirred zone was observed. }\end{array}$ \\
\hline 3 & Yang et al. [9] & $\mathrm{AA} 2024 / \mathrm{Al}_{2} \mathrm{O}_{3}$ & Mechanical Properties & $155 \mathrm{HV}$ & $\begin{array}{l}\text { Maximum hardness was obtained on stir } \\
\text { zone. }\end{array}$ \\
\hline & & & & & $\begin{array}{l}\text { Tensile property of cold sprayed } \\
\text { composite was enhanced with FSP. }\end{array}$ \\
\hline 4 & $\begin{array}{l}\text { Sahraeinejad } \\
\text { et al. [10] }\end{array}$ & $\begin{array}{l}\mathrm{Al} 5059 / \mathrm{Al}_{2} \mathrm{O}_{3} \\
\mathrm{SiC} \text { and } \mathrm{B}_{4} \mathrm{C}\end{array}$ & Mechanical Properties & & $\begin{array}{l}\mathrm{Al}_{2} \mathrm{O}_{3} \text { had better grain refinement. } \\
\mathrm{B} 4 \mathrm{C} \text { reinforced composite had improved } \\
\text { tensile and yield strength with reduced } \\
\text { ductility. }\end{array}$ \\
\hline 5 & Kumar et al. [11] & $\mathrm{Al} 5083 / \mathrm{Ni}$ & $\begin{array}{l}\text { Influence of } \\
\text { reinforced particle } \\
\text { size was evaluated }\end{array}$ & & $\begin{array}{l}\text { Particle size of } 70 \mu \mathrm{m} \text { had accumulation } \\
\text { of Ni particles, leads to fracture during } \\
\text { FSP. }\end{array}$ \\
\hline 6 & Bauri et al. [12] & Al 5083/Ni & $\begin{array}{l}\text { Mechanical } \\
\text { Characteristics }\end{array}$ & $91 \mathrm{HV}$ & $\begin{array}{l}\text { Recrystallization of the matrix had } \\
\text { refined the grain size from } 25 \text { to } 3 \mu \mathrm{m} \text {. } \\
\text { Minimum } 1,200 \mathrm{rpm} \text { of tool rotation } \\
\text { speed and } 0.4 \mathrm{~mm} / \mathrm{sec} \text { of TS was } \\
\text { required to incorporate Ni particles. }\end{array}$ \\
\hline 7 & $\begin{array}{l}\text { Huang and Shen } \\
{[13]}\end{array}$ & $\mathrm{Al} 5083 / \mathrm{Ti}$ & $\begin{array}{l}\text { Micro structural } \\
\text { Properties }\end{array}$ & & $\begin{array}{l}\text { Cooling effect of water had refined the } \\
\text { grain size of the composite. } \\
\text { Water FSPed had maximum tensile } \\
\text { strength of } 423 \mathrm{MPa} \text {. }\end{array}$ \\
\hline 8 & $\begin{array}{l}\text { Kishan and } \\
\text { Devraju [15] }\end{array}$ & $\begin{array}{l}\mathrm{Al} 6061 / \text { nano } \\
\mathrm{TiB}_{2}\end{array}$ & $\begin{array}{l}\text { Mechanical } \\
\text { Characteristics }\end{array}$ & $104 \mathrm{HV}$ & $\begin{array}{l}\text { Decrease in tensile strength was found } \\
\text { due to accumulation of nano } \mathrm{TiB}_{2} \\
\text { particles. }\end{array}$ \\
\hline 9 & $\begin{array}{l}\text { Dinaharan and } \\
\text { Akinlabi [16] }\end{array}$ & $\begin{array}{l}\mathrm{Al}, \mathrm{Mg}, \mathrm{Cu} / \mathrm{Fly} \\
\text { Ash }\end{array}$ & $\begin{array}{l}\text { Mechanical } \\
\text { Characteristics }\end{array}$ & $\begin{array}{l}125,110 \text { and } \\
170 \text { VHN }\end{array}$ & $\begin{array}{l}\text { Uniform Distribution of Fly Ash is } \\
\text { found in } \mathrm{Al}, \mathrm{Mg} \text { and } \mathrm{Cu} \text { Matrix. }\end{array}$ \\
\hline 10 & $\begin{array}{l}\text { Dhayalan et al. } \\
\text { [17] }\end{array}$ & AA6063/SiC-Gr & $\begin{array}{l}\text { Characterization } \\
\text { Property }\end{array}$ & $62 \mathrm{HV}$ & $\begin{array}{l}\text { Uniform dispersal of reinforced particle } \\
\text { was observed. }\end{array}$ \\
\hline 11 & Rathee et al. [18] & AA $6063 / \mathrm{SiC}$ & Mechanical Properties & $80 \mathrm{HV}$ & $\begin{array}{l}\text { Tensile strength was improved to } 175 \\
\text { MPa. }\end{array}$ \\
\hline 12 & $\begin{array}{l}\text { Abraham et al. } \\
\text { [20] }\end{array}$ & AA $6063 / \mathrm{SiO}_{2}$ & $\begin{array}{l}\text { Micro structural and } \\
\text { Wear properties }\end{array}$ & $135 \mathrm{HV}$ & $\begin{array}{l}\text { Micro hardness was increased with the } \\
\text { increase of } \mathrm{SiO}_{2} \text { content. } \\
\text { Wear rate was reduced by } 258 \times 10^{-5} \\
\mathrm{~mm}^{3} / \mathrm{m} \text { at } 18 \text { vol. } \% \text { of } \mathrm{SiO}_{2} \text { particles. }\end{array}$ \\
\hline 13 & $\begin{array}{l}\text { Selvakumar et } \\
\text { al. [21] }\end{array}$ & Al 6082/Mo & $\begin{array}{l}\text { Characterization } \\
\text { Property }\end{array}$ & & $\begin{array}{l}\text { No accumulation of Mo particle was } \\
\text { observed. } \\
\text { Tensile strength was improved to } 305 \\
\text { MPa at } 18 \text { vol. } \% \text { of Mo particles. }\end{array}$ \\
\hline 14 & $\begin{array}{l}\text { Selvakumar et } \\
\text { al. [22] }\end{array}$ & $\begin{array}{l}\text { AA } 6082 / \\
\text { stainless steel }\end{array}$ & $\begin{array}{l}\text { Mechanical } \\
\text { Characteristics }\end{array}$ & & $\begin{array}{l}\text { The UTS was improved to } 293 \mathrm{MPa} \text { at } \\
18 \text { vol. } \% \text { while ductility was measured } \\
\text { to be } 17 \% \text { at } 18 \text { vol. } \% \text {. }\end{array}$ \\
\hline 15 & Du et al. [23] & $\mathrm{Al} / \mathrm{Al}_{2} \mathrm{O}_{3} / \mathrm{CNTs}$ & $\begin{array}{l}\text { Mechanical } \\
\text { Characteristics }\end{array}$ & $108.4 \mathrm{HV}$ & $\begin{array}{l}\text { The tensile strength of } \mathrm{Al} / \mathrm{Al}_{2} \mathrm{O}_{3} / \mathrm{CNTs} \\
\text { composite was found to be } 263 \mathrm{MPa} \text {. }\end{array}$ \\
\hline 16 & $\begin{array}{l}\text { Dinaharan et al. } \\
\text { [24] }\end{array}$ & $\begin{array}{l}\mathrm{Cu} / \text { Rice husked } \\
\text { ash }\end{array}$ & $\begin{array}{l}\text { Mechanical and Wear } \\
\text { Properties }\end{array}$ & $105 \mathrm{VHN}$ & $\begin{array}{l}\text { The wear rate was reduced to } 5.3 \times 10^{-3} \\
\text { mm } 3 / \mathrm{m} \text { by incorporating } 18 \text { vol. } \% \text { of the } \\
\text { RHA particles. }\end{array}$ \\
\hline
\end{tabular}



[26]

Golmohammadi A413/Ni
et al. [27]

Esfahani et al. [28]

2

Yuvraj et al. [30]

$\mathrm{Al} 5083 / \mathrm{B}_{4} \mathrm{C}$ micro- and nano particles

Kumar et al. [31]
Esmaily et al. [34]

Rao and Rao

[35]

\section{[38]}

[39]

39]

Thangarasu et al. [40]

Ambigai and

Prabhu [41]

34 Bhat et al. [42]

Rajan et al. [43]

Eskandari and Taheri [46]

39 Zangabad et al. [47]

$40 \quad$ Azizieh et al. [48]
Micro structural and Mechanical Properties

Tribological

Properties

Mechanical and Wear $80 \mathrm{HV}$

Characteristics

Tribological

Properties

Tribological

Properties

Tribological

Properties

Wear characteristics

Mechanical and

Wear Properties

Mechanical and

Wear Properties

$\mathrm{B}_{4} \mathrm{C} / \mathrm{SiC} / \mathrm{TiC}$

AA $7075 / \mathrm{TiB}_{2}$

$\mathrm{Al}_{2} \mathrm{O}_{3}, \mathrm{TiC}$

$\mathrm{B}_{4} \mathrm{C}$ and $\mathrm{WC}$

AA $6082 / \mathrm{TiC}$

$\mathrm{Al} / \mathrm{B}_{4} \mathrm{C}$

$\mathrm{Al} / \mathrm{Fe}$

Al 7075-2\% SiC micro- and nano particles

Al

Mechanical

characteristics

Wear

Properties

Mechanical

Properties

Mechanical and Wear

Properties

Micro structural

Properties

Mechanical and Wear Characteristics

Wear Properties

Wear Characteristics

Microstructural

Properties

Micro structural and

Mechanical Properties

Wear Properties

Mechanical Properties

Mechanical Properties

Fatigue Behaviour

$\mathrm{Al} / \mathrm{Al}_{3} \mathrm{Ti} / \mathrm{MgO}$

$\mathrm{Al} / \mathrm{Al}_{2} \mathrm{Cu}$

Microstructural and Wear Properties
$117.3 \mathrm{HV}$

$105 \mathrm{HV}$

$70 \mathrm{VHN}$

$145 \mathrm{HV}$

$116 \mathrm{HV}$ and

$124.8 \mathrm{HV}$

$126.7 \mathrm{HV}$

$112 \mathrm{HV}$

$101 \mathrm{HV}$, $121 \mathrm{HV}$

$175 \mathrm{HV}$

The compressive strength was improved to $40 \%$ and $30 \%$ for hardness.

The wear loss was reduced with lubricating $\mathrm{SiC}$ particles by $\mathrm{MoS}_{2}$.

Wear resistance was improved for three pass composites in comparison to casted or single pass composite.

Fe particles had improved the wear resistance.

$\mathrm{SiC}$ particles had increased the micro hardness. Wear rate was reduced in the processed zone.

Nano particles had enhanced the micro hardness in compare to micro particles.

Adhesive wear mechanism was observed at low loads. $5 \times 10^{-3} \mathrm{~mm}^{3} / \mathrm{m}$ was the wear rate for $\mathrm{Al}$ 5083 /W composite.

$140 \mathrm{HV}$ Composite having 8 passes had got the maximum grain refined structure.

$132 \mathrm{HV} \quad 18 \times 10^{-5} \mathrm{~mm}^{3} / \mathrm{Nm}$ was the minimum wear rate for AA 5083/B 4 C composite.

$120 \mathrm{HB} \quad \mathrm{V}$ shape and step grove had got more uniform distribution in comparison to square groove.

The wear resistance of AA $6061 / \mathrm{TiB}_{2}$ composite was improved.

4 vol. \% of nano $\mathrm{TiB}_{2}$ composite exhibit improved mechanical properties.

The micro hardness was found to be 135 HV at $80 \quad \mathrm{~mm} / \mathrm{min}$ with the wear rate of $412 \times 10^{-5} \mathrm{~mm}^{3} / \mathrm{m}$.

Tensile strength was improved to 324 $\mathrm{MPa}$ at $24 \mathrm{vol} \%$ of TiC particles.

Wear rate was reduced to $300 \times 10^{-5}$ $\mathrm{mm}^{3} / \mathrm{m}$ for AA6082/24 vol.\% TiC particles.

105, 85, TiC reinforced composite had maximum 115 , 108 and 85 HV micro hardness and minimum wear rate in comparison to $\mathrm{SiC}, \mathrm{Al}_{2} \mathrm{O}_{3}, \mathrm{~B}_{4} \mathrm{C}$ and WC particles.

The wear resistance was improved to be $0.00303 \mathrm{mg} / \mathrm{m}$ at $22 \mathrm{vol} . \%$.

Nano B4C particles had got less wear rate as compared to micro $\mathrm{B}_{4} \mathrm{C}$ particles. High degree of metastability leads to poor creep resistance.

$160 \mathrm{VHN}$ Intergranular distribution of reinforced particles was observed. Wear rate was reduced to $98 \mathrm{~mm}^{3} / \mathrm{m}$ for AA7075/9wt\% TiB2.

Micro hardness was increased with the increase of transverse speed. Lower transverse speed leads to uniform dispersa of reinforced particles.

Nano SiC particles had got less wear rate as compared to micro $\mathrm{SiC}$ particles.

Less wear loss was observed for prepared nano composite.

Micro hardness was doubled for the fabricated hybrid composite.

Fatigue strength was improved to $33 \%$ by incorporating 3.5 vol. $\%$ of $\mathrm{TiO}_{2}$ particles.

Increased number of passes had refined the grain structure. 


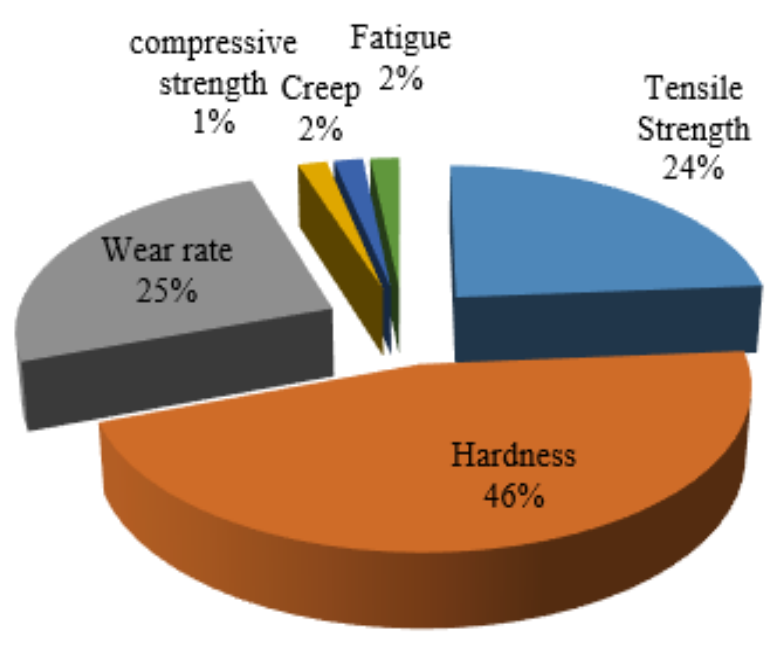

Figure 3. Summary of percentage contribution of research work on mechanical properties

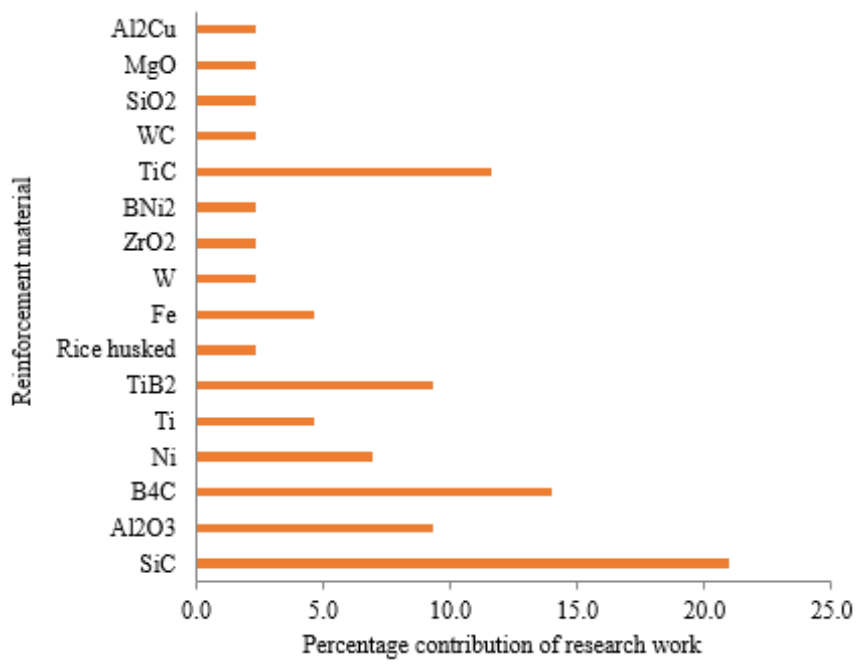

Figure 4. Summary of percentage contribution of research work on reinforcement particles

\section{CONCLUSION}

FSP has been positively developed as a composite manufacture technique. The main problem in generation of ex situ composites wherein the reinforcement is added externally to the material is the accumulation of reinforced particles. FSP leads to plastic strain, can shear the metal powders and break the oxide film around the reinforced particles. This intimates the contact between the matrix and the reinforcement to form the reaction. The chance of formation of clusters of reinforced particles can be abridged by suitable selection of an FSP tool shoulder diameter, pin diameter and tilt angle, mainly accountable for the generation of frictional and shear force. Pretreatment of the reinforced particles to improve wettability, together with multi pass FSP, offers another substitute to avoid cluster formation of reinforced particles in the FSP nugget zone. Heat generated between the tool and the surface is an important factor to produce defect free surface composite. Increased friction coefficient may lead to stick the work piece and the tool shoulder while reduced friction coefficient may not generate the heat required to make the material soft. Reinforcements acting as pinning sites refined the grain structure and thus improving the mechanical and wear properties of the surface composites.

Thus, the effective use of the FSP technique in generating composites firmly creates it in the field of composite fabrication. Further research determinations in this field and better understanding of the process features can pave the way for the commercial success of the FSP technique.

\section{REFERENCES}

[1] Dwivedi, S.P., Maurya, N.K., Maurya, M. (2019). Effect of uncarbonized eggshell weight percentage on mechanical properties of composite material developed by electromagnetic stir casting technique. Revue des Composites et des Matériaux Avancés, 29(2): 101-107. https://doi.org/10.18280/rcma.290205

[2] Maurya, N.K., Maurya, M., Srivastava, A.K., Dwivedi, S.P., Kumar, A., Chauhan, S. (2019). Investigation of mechanical properties of Al 6061/SiC composite prepared through stir casting technique. Materials Today: Proceedings.

https://doi.org/10.1016/j.matpr.2019.09.003

[3] Maurya, M., Maurya, N.K., Bajpai, V. (2019). Effect of $\mathrm{SiC}$ reinforced particle parameters in the development of aluminium based metal matrix composite. Evergreen Joint Journal of Novel Carbon Resource Sciences \& Green Asia Strategy, 6(3): 200-206.

[4] Maurya, N.K., Maurya, M. (2017). Fabrication of A359 alloy reinforced with $\mathrm{B} 4 \mathrm{C}$ particulates \& characterization of mechanical properties. International Journal of Advance Research in Science and Engineering, 6: 532538.

[5] Maurya, M., Kumar, S., Bajpai. V. (2019). Assessment of the mechanical properties of aluminium metal matrix composite: A review. Journal of Reinforced Plastics and Composites, 38(6): 267-298. https://doi.org/10.1177/0731684418816379

[6] Arab, S.M., Karimi, S., Jahromi, S.A.J., Javadpour, S., Zebarjad, S.M. (2015). Fabrication of novel fiber reinforced aluminum composites by friction stir processing. Materials Science \& Engineering A, 632: 5057. https://doi.org/10.1016/j.msea.2015.02.032

[7] Sharma, V., Prakash, U., Kumar, B.V.M. (2015). Microstructural and mechanical characteristics of AA2014/SiC surface composite fabricated by friction stir processing. Materials Today: Proceedings, 2: 2666-2670. https://doi.org/10.1016/j.matpr.2015.07.229

[8] Hosseinzadeh, A., Yapici, G.G. (2018). High temperature characteristics of $\mathrm{A} 12024 / \mathrm{SiC}$ metal matrix composite fabricated by friction stir processing. Material Science and Engineering: A, 731: 487-494. https://doi.org/10.1016/j.msea.2018.06.077

[9] Yang, K., Li, W., Niu, P., Yang, X., Xu, Y. (2018). Cold sprayed AA2024/ $\mathrm{Al}_{2} \mathrm{O}_{3}$ metal matrix composites improved by friction stir processing: Microstructure characterization, mechanical performance and strengthening mechanisms. Journal of Alloys and Compounds, 736: 115-123. https://doi.org/10.1016/j.jallcom.2017.11.132

[10] Sahraeineja, S., Izadi, H., Haghshenas, M., Gerlich, A.P. (2015). Fabrication of metal matrix composites by friction stir processing with different Particles and processing parameters. Materials Science \& Engineering A, $626:$ 505-513. 
https://doi.org/10.1016/j.msea.2014.12.077

[11] Kumar, C.N.S., Yadav, D., Bauri, R., Ram, G.D.J. (2015). Effects of ball milling and particle size on microstructure and properties $5083 \mathrm{Al}-\mathrm{Ni}$ composites fabricated by friction stir processing. Materials Science \& Engineering A, 645: 205-212. https://doi.org/10.1016/j.msea.2015.08.026

[12] Bauri, R., Ram, G.D.J., Yadav, D., Kumar, C.N.S. (2015). Effect of process parameters and tool geometry on fabrication of Ni particles reinforced $5083 \mathrm{Al}$ composites by friction stir processing. Materials Today: Proceedings, 2(4-5): 3203-3211 https://doi.org/10.1016/j.matpr.2015.07.115

[13] Huang, G., Shen, Y. (2017). The effects of processing environments on the microstructure and mechanical properties of the $\mathrm{Ti} / 5083 \mathrm{Al}$ composites produced by friction stir processing. Journal of Manufacturing Processes, 30: 361-373. https://doi.org/10.1016/j.jmapro.2017.10.007

[14] Papantoniou, I.G., Kyriakopoulou, H.P., Pantelis, D.I., Manolakos, D.E. (2018). Fabrication of MWCNTreinforced $\mathrm{Al}$ composite local foams using friction stir processing route. The International Journal of Advanced Manufacturing Technology, 97: 675-686. https://doi.org/10.1007/s00170-018-1964-3

[15] Kishana, V., Devaraju, A. (2017). Preparation of nano surface layer composite $\left(\mathrm{TiB}_{2}\right) \mathrm{p}$ on 6061-T6 Aluminum Alloy via Friction Stir Processing. Materials Today: Proceedings, 4(2): 4065-4069. https://doi.org/10.1016/j.matpr.2017.02.309

[16] Dinaharan, I., Akinlabi, E.T. (2018). Low cost metal matrix composites based on aluminum, magnesium and copper reinforced with fly ash prepared using friction stir processing. Composites Communications, 9: 22-26. https://doi.org/10.1016/j.coco.2018.04.007

[17] Dhayalan, R., Kalaiselvan, K., Kumar, R.S. (2014). Characterization of AA6063/SiC-Gr surface composites produced by FSP technique. Procedia Engineering, 97: 625-631. https://doi.org/10.1016/j.proeng.2014.12.291

[18] Rathee, R., Maheshwari, S., Siddiquee, A.N., Srivastava, M. (2017). Investigating effects of groove dimensions on microstructure and mechanical properties of AA6063/SiC surface composites produced by friction stir processing. Trans Indian Institute of Metals, 70: 809816. https://doi.org/10.1007/s12666-017-1060-7

[19] Gangil, N., Maheshwari, S., Siddiquee, A.N. (2017). Multipass FSP on AA6063-T6 Al/SiC:Strategy to fabricate surface composites. Materials and manufacturing Processes, 33(7): 805-811. https://doi.org/10.1080/10426914.2017.14154481

[20] Abraham, S.J., Madane, S.C.R., Dinaharan, I., Baruch, J. (2016). Development of quartz particulate reinforced AA6063 aluminum matrix composites via friction stir processing. Journal of Asian Ceramic Societies, 4(4): 381-389. https://doi.org/10.1016/j.jascer.2016.08.001

[21] Selvakumar, S., Dinaharan, I., Palanivel, R., Babu, B.G. (2017). Characterization of molybdenum particles reinforced Al6082 aluminum matrix composites with improved ductility produced using friction stir processing. Materials Characterization, 125: 13-22. https://doi.org/10.1016/j.matchar.2017.01.016

[22] Selvakumar, S., Dinaharan, I., Palanivel, R., Babu, B.G. (2017). Development of stainless-steel particulate reinforced AA6082 aluminum matrix composites with enhanced ductility using friction stir processing. Materials Science and Engineering: A, 685: 317-326. https://doi.org/10.1016/j.msea.2017.01.022

[23] Du, Z., Tan, M.J., Guo, J.F, Bi, G., Wei, J. (2016). Fabrication of a new $\mathrm{Al}-\mathrm{Al}_{2} \mathrm{O}_{3}-\mathrm{CNTs}$ composite usingfriction stir processing (FSP). Materials Science \& Engineering A, 667: 125-131. https://doi.org/10.1016/j.msea.2016.04.094

[24] Dinaharan, I., Kalaiselvan, K., Akinlabi, E.T., Davim, J.P. (2017). Microstructure and wear characterization of rice husk ash reinforced copper matrix composites prepared using friction stir processing. Journal of Alloys and Compounds, 718: 150-160. https://doi.org/10.1016/j.jallcom.2017.05.117

[25] Kurtyka, P., Rylko, N., Tokarski, T., Wójcicka, A., Pietras, A. (2015). Cast aluminium matrix composites modified with using FSP process - Changing of the structure and mechanical properties. Composite Structures, 133: 959-967. https://doi.org/10.1016/j.compstruct.2015.07.122

[26] Janbozorgi, M., Shamanian, M., Sadeghian, M., Sepehrinia, P. (2017). Improving tribological behavior of friction stir processed A413/SiCp surface composite using $\mathrm{MoS}_{2}$ lubricant particles. Transactions of Nonferrous Metals Society of China, 27(2): 298-304. https://doi.org/10.1016/S1003-6326 (17)60034-7

[27] Golmohammadi, M., Atapour, M., Ashrafi, A. (2015). Fabrication and wear characterization of an A413/Ni surface metal matrix composite fabricated via friction stir processing. Materials and Design, 85: 471-482. https://doi.org/10.1016/j.matdes.2015.06.09

[28] Esfahani, M.M., Manesh, H.D., Esmailzadeh, M., Roshanaei, E. (2018). Microstructure and wear properties of $1050 \mathrm{Al} / \mathrm{Fe}$ surface composites by friction stir processing. Materials Research Express, 5. https://doi.org/10.1088/2053-1591/aae145

[29] Abreu, C.M., Acuna, R., Cabeza, M., Cristobal, M.J., Merino, P., Verdera, D. (2017). Microstructure and mechanical properties of $\mathrm{Al} / \mathrm{SiC}$ composite surface layer produced by friction stir processing. Ciencia \& Tecnologia dos Materiais, 29(1): e82-e86. https://doi.org/10.1016/j.ctmat.2016.07.001

[30] Yuvaraj, N., Aravindan, S., Vipin. (2015). Fabrication of A15083/B4C surface composite by friction stir processing and its tribological characterization. Journal of Materials Research and Technology, 4(4): 398-410. https://doi.org/10.1016/j.jmrt.2015.02.006

[31] Kumar, C.N.S., Bauri, R., Yadav, D. (2016). Wear properties of 5083Al-W surface composite fabricated by friction stir processing. Tribology International, 101: 284-290. https://doi.org/10.1016/j.triboint.2016.04.033

[32] Mirjavadi, V., Alipour, M., Hamouda, A.M.S., Matin, A., Kord, S., Afshari, B.M., Koppad, P.G. (2017). Effect of multi-pass friction stir processing on the microstructure, mechanical and wear properties of AA5083/ $/ \mathrm{ZrO}_{2}$ nanocomposites. Journal of Alloys and Compounds, 726 : 1262-1273

https://doi.org/10.1016/j.jallcom.2017.08.084

[33] Kumar, V., Jain, S., Muhammed, P.M., Muthukumaran, S., Babu, S.P.K. (2018). Microstructure, mechanical and sliding wear behavior of AA5083-B4C/SiC/TiC surface composites fabricated using friction stir processing. Transactions of the Indian Institute of Metals, 71(6): 1519-1529. https://doi.org/10.1007/s12666-018-1287-y 
[34] Esmaily, H., Habibolahzade, A., Tajally, M. (2017). Parametric investigation of A15456/BNi-2 composite properties fabricated by friction stir processing. Journal of Alloys and Compounds, 725: 1044-1054. https://doi.org/10.1016/j.jallcom.2017.07.134

[35] Rao, C.M., Rao, K.M. (2018). Abrasive wear behaviour of $\mathrm{TiB}_{2}$ fabricated aluminum 6061. Materials Today: Proceedings, 5 : 268-275. https://doi.org/10.1016/j.matpr.2017.11.082

[36] Kishan, V., Devaraju, A., Lakshmi, K.P. (2018). Tribological properties of nano $\mathrm{TiB}_{2}$ particle reinforced 6061-T6 aluminum alloy surface composites via friction stir processing. Materials Today: Proceedings, 5: 16151619. https://doi.org/10.1016/j.matpr.2017.11.254

[37] Thangarasu, A., Murugan, N., Dinaharan, I., Vijay, S.J. (2014). Influence of transverse speed on microstructural and mechanical properties of AA 6082-TiC surface composite fabricated by Friction Stir Processing. Procedia Material Science, 5: 2115-2121. https://doi.org/10.1016/j.mspro.2014.07.547

[38] Thangarasu, A., Murugan, N., Dinaharan, I., Vijay, S.J. (2015). Synthesis and characterization of titanium carbide particulate reinforced AA6082 aluminium alloy composites via friction stir processing. Archieves of Civil and Mechanical Engineering, 15: 324-334. https://doi.org/10.1016/j.acme.2014.05.010

[39] Dinaharan, I., Murugan, N., Thangarasu, A. (2016). Development of empirical relationships for prediction of mechanical and wear properties of AA6082 aluminum matrix composites produced using friction stir processing. Engineering Science and Technology, an International Journal, $19(3)$ : 1132-1142. https://doi.org/10.1016/j.jestch.2016.02.004

[40] Thangarasu, A., Murugan, N., Dinaharan, I. (2014). Production and wear characterization of AA6082 -TiC surface composites by friction stir processing. Procedia Engineering, 97:

590-597. https://doi.org/10.1016/j.proeng.2014.12.287

[41] Ambigai, R., Prabhu, S. (2017). Experimental and ANOVA analysis on tribological behavior of $\mathrm{Al} / \mathrm{B} 4 \mathrm{C}$ micro and nano composite. Australian Journal of Mechanical Engineering, 17(2): 53-63. https://doi.org/10.1080/14484846.2017.1299663

[42] Bhat, U.K., Udupa, R.K., Huilgol, S.P.P. (2016). Microstructure and impression creep behavior of al based surface composite produced by friction stir processing.
Transactions of the Indian Institute of Metals, 69(2): 623627. https://doi.org/10.1007/s12666-015-0758-7

[43] Rajan, H.B.M., Dinaharan, I., Ramabalan, S., Akinlabi, E.T. (2016). Influence of friction stir processing on microstructure and properties of $\mathrm{AA} 7075 / \mathrm{TiB}_{2}$ in situ composite. Journal of Alloys and Compounds, 657: 250260. https://doi.org/10.1016/j.jallcom.2015.10.108

[44] Rana, H.G., Badheka, V.J., Kumar, A. (2016). Fabrication of A17075 / B4C surface composite by novel Friction Stir Processing (FSP) and investigation on wear Properties. Procedia Technology, 23: 519-528. https://doi.org/10.1016/j.protcy.2016.03.058

[45] Kumar, A., Pal, K., Mula, S. (2017). Simultaneous improvement of mechanical strength, ductility and corrosion resistance of stir cast Al7075-2\% SiC microand nano composites by friction stir processing. Journal of Manufacturing Processes, 30: 1-13. https://doi.org/10.1016/j.jmapro.2017.09.005

[46] Eskandari, H., Taheri, R. (2015). A Novel Technique for development of aluminum alloy Matrix/ $/ \mathrm{TiB}_{2} / \mathrm{Al}_{2} \mathrm{O}_{3}$ hybrid surface nanocomposite by friction stir processing. Procedia Materials Science, 11: 503-508. https://doi.org/10.1016/j.mspro.2015.11.080

[47] Zangabad, P.S., Khodabakhshi, F., Simchi, A., Kokabi, A.H. (2016). Fatigue fracture of friction-stir processed Al-Al3Ti-MgO hybrid Nano composites. International Journal of Fatigue, 87: 266-278. https://doi.org/10.1016/j.ijfatigue.2016.02.007

[48] Azizieh, V., Iranparast, D., Dezfuli, M.A.G., Balak, Z., Kim, H.S. (2017). Fabrication of $\mathrm{Al} / \mathrm{Al}_{2} \mathrm{Cu}$ in situ nano composite via friction stir processing. Transactions of Nonferrous Metals Society of China, 27(4): 779-788. https://doi.org/10.1016/S1003-6326 (17)60089-X

[49] MA., Z.Y. (2008). Friction stir processing technology: A review. Metallurgical and Materials Transactions A, 39(3): 642-658. https://doi.org/10.1007/s11661-0079459-0

[50] Mishra, R.S., Ma, Z.Y., Charit, I. (2003). Friction stir processing: A novel technique for fabrication of surface composite. Materials Science and Engineering: A, 341(12): 307-310. https://doi.org/10.1016/S09215093(02)00199-5

[51] Kocovic, V., Mitrovic, S., Mihajlovic, G., Mijatovic, M., Bogdanovic, B., Vukelic, D., Tadic, B. (2017). Applications of friction stir processing during engraving of soft materials. Tribology in Industry, 37(4): 434-439. 